\section{O-289 前立腺癌と倁煙，肥满の関係}

下葉大学

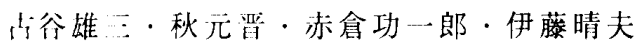

[目的]前立腺癌の進展と喫煙, 肥満の関係につ いて検傠した。[対象と方法]千葉大学で初回燎 法を施行した病期 D 2 前立腺癌 123 例, B-D 1の 119 例老対象として, 喫煙者(診断前 5 年以 内に加1日10本5年以上続けた例），肥満 度と腫場側因子，内分泌療法の反応性，予後因 子 (病期D 2 はCause-specific survivalにて, B D1はDistase-freesurvivalにて) を検討した。 観察期間はそれぞれ平均 39.8 个月,34.8 月， 中央值 29 ケ月, 28 ケであった。[結果]病期 D 2 では契煙，肥満度は予後に関係しなかった。統 尌学的有意差は認めなかったが, 非契煙者では 肥満者の方が予後が琹い傾问にあった。契煙者 は肥満度が低い傾问にあった（カイ二...乗検 笔)。また契煙者は低分化癌が多い傾向にあっ た。病期 B-D 1 では肥満者は予後の悪い傾向にあっ た。契煙者でも予後に差を認めなかった。契煙 と分化度には差を認めなかった。[結諭］喫煙， 肥満は前立腺癌に対し墨影響を及ばす可能性が 小唆された。

\section{O-291 前立腺癌、前立腺肥大症、前立腺高度異型過 形成における $r \mathrm{Sm} / \mathrm{tPSA}$ 比率の検討}

厚生連長岡中央綜合病院 ${ }^{12}$. 新潟県厚生連病理センター ${ }^{21}$ 西山勉 ${ }^{1)}$. 照沼正博 ${ }^{1)}$ ・五十嵐俊彦 ${ }^{21}$. 石崎敬 ${ }^{2)}$

【目的】血液中の前立腺特異抗原 (PSA) は free-type PSA (fPSA) と $\alpha 1$-antichymotripsin (ACT) との結合型 (ACTPSA)が PSA 測定の時問題になる。 $\gamma$-seminoprotein $(\gamma \mathrm{Sm})$ は fPSA を測定していると言われている。我々が用いてい る TOSOH AIA-PACK PA assay は fPSA とACT-PSA の両方を 测定している(tPSA)。今回、病理組織学的に診断されて いる転移を認めない前立腺癌 (PCA) 未治療症例、前立腺肥 大症 $(\mathrm{BPH})$ 症例、ならびに高度異型過形成 (PIN) 症例の $\gamma$ $\mathrm{Sm} / \mathrm{tPSA}$ 比率を検討した。【対象と方法】対象は生検なら びに TUR-P 標本により病理組織学的に診断されている $\mathrm{Sm}>1.5 \mathrm{ng} / \mathrm{ml} O$ 転移を認めないPCA 未治療症例 27 例、BPH 66 例、PIN 4 例であった。tPSA ならびに $\gamma \mathrm{Sm}$ の測定は生検 またはTU-R 前に行われた。【結果】PCA 症例の TPSA は 5.7 $\sim 366 \mathrm{ng} / \mathrm{ml}$ 、平均 $79.1 \mathrm{ng} / \mathrm{ml} 、 \gamma \mathrm{Sm}$ は $1.6 \sim 24.1 \mathrm{ng} / \mathrm{ml}$ 、 平均 $16.3 \mathrm{ng} / \mathrm{ml} 、 \gamma \mathrm{Sm} / \mathrm{tPSA}$ 比率は $0.059 \sim 0.787$ で、平均 0.272 であった。 BPH 症例の tPSA は $1.4 \sim 38.6 \mathrm{ng} / \mathrm{ml}$ 、平 均 $8.9 \mathrm{ng} / \mathrm{ml} 、 \gamma \mathrm{Sm}$ は $1.6 \sim 20.2 \mathrm{ng} / \mathrm{ml}$ 、平均 $5.8 \mathrm{ng} / \mathrm{ml}$ で、 $\gamma \mathrm{Sm} / \mathrm{tPSA}$ 比率は $0.115 \sim 2.391 \mathrm{ng} / \mathrm{m} 1$ 、平均 0.755 で あった。PIN 症例では tPSA は $6.8 \sim 27.4 \mathrm{ng} / \mathrm{ml}$ 、平均 $8.9 \mathrm{ng} / \mathrm{ml} 、 y$ Sm は $2.1 \sim 5.4 \mathrm{ng} / \mathrm{ml}$ 、平均 $3.8 \mathrm{ng} / \mathrm{ml} 、 \gamma$ $\mathrm{Sm} / \mathrm{tPSA}$ 比率は $0.186 \sim 0.368$ で、平均 0.284 であった。結 語】 $\gamma \mathrm{Sm} / \mathrm{tPSA}$ 比率では PCA 症例怡 BPH に比較して有為に 低値であった，PIN 症例では PCA 症例とほぼ同等の值を示 したことから、今後厳重な経過観察が必要と思われた。

\section{O-290 平均余命より見太前立脉烛の臨床的重要性}

北里大学医学部泌尿器科

設楽敏也、頴川 晋、伊藤啓一、斉藤 毅、竹川勝治、 古畑誠之、横田㣀二、須山一穂、小柴健

日本人男性は、他のどのpopulationよりも長寿である。 理論上、このことは小腫瘍であっても長年月の間に進行 し、やがては臨床的に問題となる可能性があることを意 味する。一般には、0.2-0.5 ccの腫瘍体糟をもって躁床上 重要であると定義していることが多い。しかし、20才の 男性にできた $0.1 \mathrm{cc}$ の腫瘍と90才の男性の2.0ccの腫演の 意義は同一ではなく、前者が将来的にも重要にはならな い保証はない。このように、腫癔体積を考慮する場合、 年齢に無関係にある値をもってカットオフ値とすること には問題がある。

1992.3より1996.9までに北里大学で経験した104例の 根治的前立腺摘除術標本上の病理所見と、平均余命、腫 瘍倍化時問で補正した腫瘍体積をもとに、前立腺癌の臨 床的意義を考察する。前立腺癌の臨床的意義を検討する 際には、宿主側の因子をも視野に入れたトータルな検討 が必須であると思われた。 \section{O-292 前立腺癌の診断における前立腺特異抗原よ
rーセミノプロテイン比の有用性の検討 浦和市立 ${ }^{\prime \prime}$. 慶應義塾大学 ${ }^{2}$

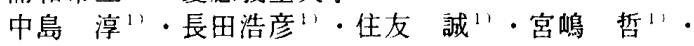 実川正道 ${ }^{1} \cdot$ 村井 勝 $^{2}$}

【目的】前立腺特異抗原(PSA) と $\gamma-$ - ミノプロテイン $(\gamma-S m)$ は同一蛋白と考えられており、 $\gamma$ 一七ノプロ テインは遊離型PSAを反映すると想定されている。前立腺 癌の診断においてPSA/ $\gamma$-Sm比がPSA単独より有用である ことが示唆されている。本研究においては、receiver operating characteristic (ROC)曲線を用いて、前立腺癌 の診断におけるPSA $/ \gamma-S m$ 比の有用性をPSAあるいは $\gamma-$ Sm単独と比較検討した。【対象および方法】血清PSA(MA RKIT-MPA)および $\gamma-S m$ が測定限界值以上を示す未治療前 立腺癌94例、前立腺肥大症62例を対象とした。

【結果】前立腺癌患者における血清 PSA、 $\gamma-S m$ および

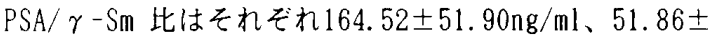
$10.26 \mathrm{ng} / \mathrm{ml}$ および2.91 0.54 であり、前立腺肥大症患者 のそれら $(4.72 \pm 0.79 \mathrm{ng} / \mathrm{ml} 、 7.08 \pm 1.08 \mathrm{ng} / \mathrm{ml}$ および 1.18土0.44）上り有意に上昇していた。前立腺癌におい ては、臨床病期や分化度の進行にともないこれらのマー カーの有意な増加が認められた。前立腺癌の診断におけ るPSA、 $\gamma-S m$ およびPSA / $\gamma-S m$ 比のROC曲線下面積はそれ ぞれ0.89、0.75および0.87であった。最も高い正診率と その時の感度ならびに特異度はPSAについては $84 \% 、 82$

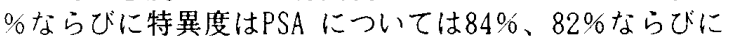
87\%であり、 $\gamma-S m$ では71\%、72\%ならびに $68 \% 、 P S A /$ $\gamma$-Sm比では81\%、91\%ならびに65\%であった。

【結語】以上の結果より、前立腺癌の診断におけるPSA/ $\gamma$-Sm比の有用性はPSA単独とほぼ同等であり、高い感度 を有する可能性が示唆された。 